\title{
Empty Fruit Bunches Compost and Germination of Raphanus
}

\author{
sativs $\mathbf{L}$.
}

\author{
RAFEAH WAHI* \& IZZATUL ‘ADILAH YUSUP \\ Department of Chemistry, Faculty of Resource Science and Technology, Universiti Malaysia Sarawak, \\ 94300 Kota Samarahan, Sarawak, Malaysia
}

\begin{abstract}
Overabundance of empty fruit bunches (EFB) from palm oil industries has opened opportunity for its exploitation for agricultural use as compost. In this study, palm oil EFB compost was prepared by the addition of wood chips as a bulking agent and chicken manure to enhance the composting rate. Moisture was maintained at $50-70 \%$ during the 2-month composting. Results showed that the EFB compost containing high mineralisation index compared to the initial EFB samples after two months of the composting process. The important macronutrients; $\mathrm{N}, \mathrm{P}, \mathrm{K}, \mathrm{Ca}$ and $\mathrm{Mg}$ and micronutrients $\mathrm{Fe}, \mathrm{Zn}, \mathrm{Mn}, \mathrm{Ni}, \mathrm{Cu}$ and $\mathrm{B}$ were found present in the EFB composts. The final stage of EFB compost B showed high nutrient content with $\mathrm{N}, \mathrm{P}$, and $\mathrm{K}$ values of $2.21 \%, 3.65 \%$, and $0.49 \%$, respectively. Fe was the most outstanding element in the EFB compost as high as $9000 \mathrm{ppm}$. Germination results showed that EFB compost with EFB:wood chips at 1:3 ratio exhibited better growth of leaves and root of Raphanus sativs L. compared to 1:2 ratio. This indicated that the EFB compost is capable in improving soil fertility and growth of plants.
\end{abstract}

Keywords: aerobic composting, oil palm empty fruit bunch, Raphanus sativs L., wood chips

\section{INTRODUCTION}

Malaysia is one of the world's largest producers of palm oil products and generated a significant amount of agricultural by-products annually, such as empty fruit bunch (EFB). It is estimated that 15 million tons of EFB is produced annually in Malaysia (Abdul et al., 2016). Current practices for managing EFB as an agricultural waste is by utilising it as mulch and fertiliser for soil conditioning (Abdul et al., 2016). However, direct application alone could not solve the problem of overabundance of EFB. In some cases EFB is incinerated to provide energy for boilers but incineration process could cause air pollution. There are also some studies looking into the potential use of EFB for sugar (Abdul et al., 2016) and bioethanol production (Sugiharto et al., 2016). However, more than often EFB are left to be naturally degraded on site, causing breeding of rhinoceros beetles and rats (Lim et al., 2015). Thus it is important to find as much ways as possible to utilise the EFB.

Another alternative for utilising EFB is by converting it into compost via composting process. During composting, a compound is stabilised either aerobically or anaerobically, and the end product could be used to enhance plant growth. Studies have been conducted on the use of EFB compost, for instance its use as additive in soilless culture system for vegetable crop production (Ismail et al., 2004), potting material for ornamental plants (Kala et al., 2009), cocomposting of EFB with chicken manure and palm oil mill effluent (POME) (Baharuddin et al., 2009), and co-composting with oil palm decanter cake (Adam et al., 2016). In this study, an attempt was made to produce EFB compost via co-composting with another wastes namely wood chips and chicken manure, under aerobic condition. The effectiveness of the compost on the growth of Raphanus sativs L. seedling was also investigated.

\section{MATERIALS \& METHODS}

\section{Materials}

The EFB and wood chips samples were collected from palm oil mills and sawmills in Kuching, Sarawak respectively. EFB samples were ground using a food grinder (SINGER) while the wood chips were shredded into size $5-20 \mathrm{~mm}$ prior to use. 


\section{Composting Process}

EFB compost was prepared in a $5 \mathrm{~L}$ rectangular composting bin with dimension of $45.5 \mathrm{~cm} \mathrm{x}$ $31.0 \mathrm{~cm} \times 25.0 \mathrm{~cm}$ and perforated walls to enable aeration. A self-heating composting bin, which rely on the microbial heat production, was used in this study to help the composting process to reach and maintain the required temperature. The EFB (500 g) and wood chips were mixed at mass ratios of 1:2 (compost $A$ ) and 1:3 (compost B). The EFB and wood chips mixture of composts A and B were sprinkled with tap-water and stirred every $48 \mathrm{~h}$ to allow optimum microbial activities in compost (labelled as early stage compost). After one month of composting, $500 \mathrm{~g}$ of chicken manure was added to compost $\mathrm{A}$ and $\mathrm{B}$ and mixed homogeneously (labelled as intermediate stage compost). The composting process was allowed for another months to obtain the final compost mixture (labelled as final stage compost). Samples from each composting stage (initial, early, intermediate, and final) were taken for proximate and ultimate analyses.

\section{Chemical Analysis}

The moisture, ash and total combustible matter content analyses were conducted based on ASTM D5142-09. Carbon (C) and Nitrogen (N) contents were analysed using a CHN analyser (Thermo Finnigan EA 1112, Italy), total organic carbon by TOC analyser (LECO, U.S.A.), functional group analysis by Fourier Transform Infra-Red (FTIR) Spectrometer (Shimadzu, Japan), and mineral content (P, K, $\mathrm{Ca}, \mathrm{Mg}, \mathrm{Fe}, \mathrm{Mn}, \mathrm{Cu}, \mathrm{Zn}$, and $\mathrm{B}$ ) by ICP-MS (Shimadzu, Japan).

\section{Germination Test}

For germination test, $R$. sativs L. seeds were used. Petri-dish germination test method was adapted from Hoekstra et al. (2002). All experiments were done in three replicates. EFB composts $(10 \mathrm{~g})$ from all three stages were mixed with deionised water $(20 \mathrm{~mL})$, shaken for $1 \mathrm{hr}$ and the suspension was gravity filtered. Seeds of $R$. sativs L. (35) were placed on twolayer filter paper in a petri dish, added with 10 $\mathrm{mL}$ of test solution, and placed in dark compartments. Deionised water was used as solution in the control experiment. Percentage of germination was recorded after 24, 48 and 72 hrs. The length of the roots was measured after $72 \mathrm{hrs}$. A $5 \mathrm{~mm}$ primary root was used as an operational definition of germination. The percentage of relative seed germination (RSG) and germination index (GI) were calculated using Equation 1 and 2, respectively, where $N_{\text {exp }}$ is the number of seed germinated in compost extract, $N_{c}$ is the number of seed germinated in control experiment, RSG is the percentage of germinated seed and $R G$ is the percentage of root growth.

$$
\begin{aligned}
& R S G, \%=\frac{N_{\text {exp }}}{N_{c}} \times 100 \% \quad \text { (Equation 1) } \\
& G I=\frac{R S G \times R G}{100} \quad(\text { Equation 2) }
\end{aligned}
$$

For the pot germination test, five seeds of $R$. sativs L. were planted in each pot consist of a homogenous mixture of $500 \mathrm{~g}$ soils and $100 \mathrm{~g}$ of composts. The control experiment pot contained 5 seeds planted in $500 \mathrm{~g}$ soils only. The seeds were watered daily. The shoot-length was measured from at day three until day 15 .

\section{RESULTS \& DISCUSSION}

\section{Chemical Characteristics of EFB Composts}

The composting process was started at room temperature, and the temperature during the twomonths composting process was at 40 to $45^{\circ} \mathrm{C}$. The increase in composting temperature occurs is most likely due to the hard-to-ferment lignocellulosic nature of the EFB substrate, whereby the lignin content in a substrate could affect decomposition rate of cellulose (El Ouaqoudi et al., 2015).

Table 1 shows that the ash content of the early, intermediate and final stage composts continually increased as the composting time increased. Both EFB compost A and EFB compost $\mathrm{B}$ showed higher ash content, about 1.5 times from initial material. Higher ash content in 
Table 1. Proximate and ultimate analysis of empty fruit bunches (EFB) compost at different EFB:wood chips ratio.

\begin{tabular}{lcccccc}
\hline Analysis & \multicolumn{2}{c}{$\begin{array}{c}\text { Raw material } \\
\text { (early stage) }\end{array}$} & \multicolumn{2}{c}{$\begin{array}{c}\text { Compost after 1 month } \\
\text { (intermediate stage) }\end{array}$} & \multicolumn{2}{c}{$\begin{array}{c}\text { Compost after 2 months } \\
\text { (final stage) }\end{array}$} \\
\cline { 2 - 7 } & $1: 2(\mathrm{~A})$ & $1: 3(\mathrm{~B})$ & $1: 2(\mathrm{~A})$ & $1: 3(\mathrm{~B})$ & $1: 2(\mathrm{~A})$ & $1: 3(\mathrm{~B})$ \\
\hline Ash (wt\%) & $50.21 \pm 0.8$ & $49.21 \pm 0.2$ & $64.23 \pm 0.3$ & $70.67 \pm 0.7$ & $75.07 \pm 0.5$ & $71.91 \pm 0.8$ \\
Combustibles (wt\%) & $38.56 \pm 0.8$ & $40.85 \pm 0.3$ & $22.33 \pm 0.4$ & $16.74 \pm 0.8$ & $12.23 \pm 0.7$ & $15.52 \pm 0.8$ \\
Carbon (\%) & 48.38 & 46.90 & 33.16 & 19.30 & 18.54 & 23.70 \\
Nitrogen (\%) & 1.03 & 0.59 & 3.71 & 2.24 & 2.30 & 2.21 \\
\hline
\end{tabular}

both composts compared to the raw material indicates high inorganic matter content in the composts. A high inorganic matter content in compost helps to avoid the plant from suffering root damage, seed germination inhibition and nutrient starvation which were usually caused by lack of inorganic constituents in composts (Vargas-Garcia et al., 2006). The ash content increased as the composts matured, indicating the carbon mineralisation process. Mineralisation can be expressed in the form of mineralisation index, which is the ash content/oxidisable carbon ratio. At the intermediate stage of composting, the ash content was found higher in EFB compost B compared to EFB compost A.

The observation indicated higher mineralisation occur in EFB compost B after 1 month of composting, possibly due to the higher content of wood chips as bulking agent. More bulking agent means more carbon available to balance the nitrogen produced by the compost. At the end of the composting process, EFB compost $A$ showed higher ash content compared to EFB compost B. In contrast, EFB compost B showed higher combustible matter content at the final stage of composting. Results showed that the EFB compost has high mineralisation index compared to the initial EFB samples after two months of the composting process, which were 4.05 and 3.03 for EFB compost A and B, respectively. The higher mineralisation index compared to the raw material (1.03 and 1.05 for EFB Compost A and B, respectively) indicates the maturity and stability of the compost at the final stage of composting.
The moisture content in EFB composts increased from about $50 \%$ at the beginning to $70 \%$ at the end of the composting process (see Table 2). Moisture content is an important factor in ensuring good composting, as it affects the microbial activity during the composting process. In particular, moisture content affects particle aggregation, matrix porosity, air filled porosity and also matrix gas permeability (Richard et al., 2002). High moisture content (40-60\%) enable maximum oxygen uptake into the compost (Ahn et al., 2007).

Table 1 also shows that the carbon content in compost decreased, and this is envisaged as a result of carbon mineralisation process during composting. In addition, at the end of composting process the total carbon content in EFB compost A (18.54\%) was lower compared to EFB compost B $(23.70 \%)$. Results could be linked to the higher usage of the carbon in EFB compost A by microorganism during EFB composting compared to compost B. Higher usage of carbon during composting of EFB compost A was indicated by its relatively higher $\mathrm{N}$ content at the intermediate stage compared to EFB compost B. As earlier mentioned, carbon is needed to balance the nitrogen produced by the compost. Results also shows that $\mathrm{N}$ content was higher in the final stage compost compared to the raw material. It is envisaged that the use of chicken manure during composting contributes to the nitrogen content in the final stage compose.

The $\mathrm{C} / \mathrm{N}$ ratio during early stage of composting was higher compared to the $\mathrm{C} / \mathrm{N}$ 
Table 2. Moisture content of EFB compost at different composting stage and EFB:wood chips ratio.

\begin{tabular}{lcc}
\hline Type of compost & \multicolumn{2}{c}{ Moisture content } \\
\cline { 2 - 3 } & Wet basis & Dry basis \\
\hline Compost A & & \\
Early stage & $50.21 \%$ & $11.24 \%$ \\
Intermediate stage & $51.08 \%$ & $13.55 \%$ \\
Final stage & $70.58 \%$ & $12.23 \%$ \\
& & \\
Compost B & & \\
Early stage & $53.74 \%$ & $9.95 \%$ \\
Intermediate stage & $59.80 \%$ & $12.58 \%$ \\
Final stage & $74.90 \%$ & $12.58 \%$ \\
\hline
\end{tabular}

ratio at the final stage of composting. EFB compost $\mathrm{A}$ showed $\mathrm{C} / \mathrm{N}$ ratio of 46.97 at the early stage and 8.06 at the final stage of composting. EFB compost $\mathrm{B}$ showed $\mathrm{C} / \mathrm{N}$ ratio of 76.49 at the early stage and 10.62 at the final stage of composting. The $\mathrm{C} / \mathrm{N}$ value of $\mathrm{EFB}$ compost $\mathrm{B}$ indicated its maturity. $\mathrm{C} / \mathrm{N}$ ratio of $10-15$ is typically as accepted value indicating the humic acid formation and enhanced stability of a compost (El Ouaqoudi et al., 2015).

Essential macronutrients of plants such as $\mathrm{N}$, $\mathrm{P}, \mathrm{K}, \mathrm{Ca}$ and $\mathrm{Mg}$ are highly needed for plant metabolism. These macronutrients levels (except for K) in the EFB compost increased from the early stage until the end of composting (Table 3). No clear increase in the macronutrients level between the intermediate and final stage of EFB compost, possibly due to the maturation of compost at as early as one month age. At the final stage, results show that EFB compost B contained slightly higher level of macronutrients compared to EFB compost A (Table 3). In particular, the final stage EFB compost B showed a high nutrient content with $\mathrm{N}, \mathrm{P}$, and $\mathrm{K}$ values of $2.21 \%, 3.65 \%$, and $0.49 \%$, respectively. The $\mathrm{N}, \mathrm{P}$, and $\mathrm{K}$ values were higher compared EFB compost prepared via cocomposting with palm oil decanter cake obtained in Adam et al. (2016).

Table 3. Macronutrients and micronutrients in EFB composts of different EFB:wood chips ratio.

\begin{tabular}{|c|c|c|c|c|c|c|}
\hline \multirow[b]{2}{*}{ Ratio } & \multicolumn{2}{|c|}{ Early stage } & \multicolumn{2}{|c|}{ Intermediate stage } & \multicolumn{2}{|c|}{ Final stage } \\
\hline & $1: 2(\mathrm{~A})$ & $1: 3(\mathrm{~B})$ & $1: 2(\mathrm{~A})$ & $1: 3(\mathrm{~B})$ & $1: 2(\mathrm{~A})$ & $1: 3(\mathrm{~B})$ \\
\hline \multicolumn{7}{|c|}{ Macronutrient, \% } \\
\hline $\mathrm{N}$ & 1.03 & 0.59 & 3.71 & 2.24 & 2.30 & 2.21 \\
\hline $\mathrm{C}$ & 48.38 & 46.90 & 33.16 & 19.30 & 18.54 & 23.70 \\
\hline Organic C & 14.40 & 19.30 & 20.10 & 19.80 & 49.10 & 49.30 \\
\hline $\mathrm{P}$ & 0.05 & 0.08 & 3.88 & 3.39 & 3.30 & 3.65 \\
\hline $\mathrm{K}$ & 1.24 & 1.54 & 0.57 & 0.43 & 0.44 & 0.49 \\
\hline $\mathrm{Ca}$ & 0.31 & 0.41 & 5.56 & 5.04 & 4.58 & 5.25 \\
\hline \multicolumn{7}{|c|}{ Micronutrient, ppm (unless stated otherwise) } \\
\hline $\mathrm{Mg}, \%$ & 0.12 & 0.16 & 0.86 & 0.78 & 0.80 & 0.83 \\
\hline $\mathrm{Mn}$ & 45 & 59 & 1080 & 940 & 921 & 1049 \\
\hline $\mathrm{Fe}$ & 361 & 490 & 8877 & 8608 & 7388 & 8257 \\
\hline $\mathrm{Cu}$ & 8 & 11 & 962 & 88 & 897 & 901 \\
\hline $\mathrm{Zn}$ & 31 & 38 & 1333 & 1213 & 1137 & 1266 \\
\hline $\mathrm{B}$ & 7 & 10 & 42 & 39 & 35 & 37 \\
\hline
\end{tabular}


Essential micronutrient metals such as $\mathrm{Zn}$, $\mathrm{Mn}, \mathrm{Ni}, \mathrm{Cu}$ and $\mathrm{B}$ are found higher in $\mathrm{EFB}$ compost B compared to the EFB compost A (Table 3). The observations was possibly due to EFB compost B contain more bulking agent, which contributed to the nutrient enhancement during composting. In all composts, $\mathrm{Fe}$ was the highest compared to other metals that present. $\mathrm{Fe}$ is very important in plant growth and development and deficiency of Fe on the new growth may cause interveinal chlorosis, a condition where the plant leaves are smaller than normal leaves, green leaves to turn yellow and burning colour effect on the leaf edges (Horneck et al., 2007).

The functional groups of the EFB compost samples obtained using FTIR analysis are shown in Figures 1 and 2. In general, both final stage EFB compost $\mathrm{A}$ and $\mathrm{B}$ showed quite similar spectra. The early and final stage composts also showed same absorbance peaks, which differs only in the peak intensity. The early stage composts show peaks at 3390, 1700, 1640 and $1000 \mathrm{~cm}^{-1}$, indicating the rich aromatic, phenolic, aliphatic and polysaccharide structures content in the early stage compost (El Ouaqoudi et al., 2015).
Stretching vibration at $3391 \mathrm{~cm}^{-1}$ indicates the presence of the bonded $\mathrm{OH}$ group, which may be attributed to absorbed water in the compost. Absorptions at the $2918 \mathrm{~cm}^{-1}$ and $2850 \mathrm{~cm}^{-1}$ indicate the presence of $\mathrm{CH}$ alkane (saturated $\mathrm{CH})$ in the sample, while band around 3500 $\mathrm{cm}^{-1}$ to $3000 \mathrm{~cm}^{-1}$ implies the NH stretching vibration. Peak at $1640 \mathrm{~cm}^{-1}$ to $1560 \mathrm{~cm}^{-1}$ shows the presence of primary $\mathrm{NH}$. The C-N bond is shown in the range $1350 \mathrm{~cm}^{-1}$ to $1000 \mathrm{~cm}^{-1}$. The presence of the amine and nitrile bands are important because they confirm the richness of nitrogen in the compost (Ouatmane et al., 2000).

Meanwhile, the $\mathrm{C}=\mathrm{C}$ presence is shown at $1642 \mathrm{~cm}^{-1}$. Absorption at $1620-1660 \mathrm{~cm}^{-1}$ is a sign of aromatic vibration, in addition of quinines, conjugated carbonyls and ketone, while absorptions at $1513 \mathrm{~cm}^{-1}$ and $1321 \mathrm{~cm}^{-1}$ indicate that the presence of $\mathrm{N}=\mathrm{O}$ which bonded with alkyl group.

The FTIR spectra of compost at different time exhibit the same pattern, showing that no noticeable qualitative change in the functional groups has occurred during the composting process. Changes during composting affected only the band intensities, indicating that the increase of composting time does not involve significant change in compost composition.

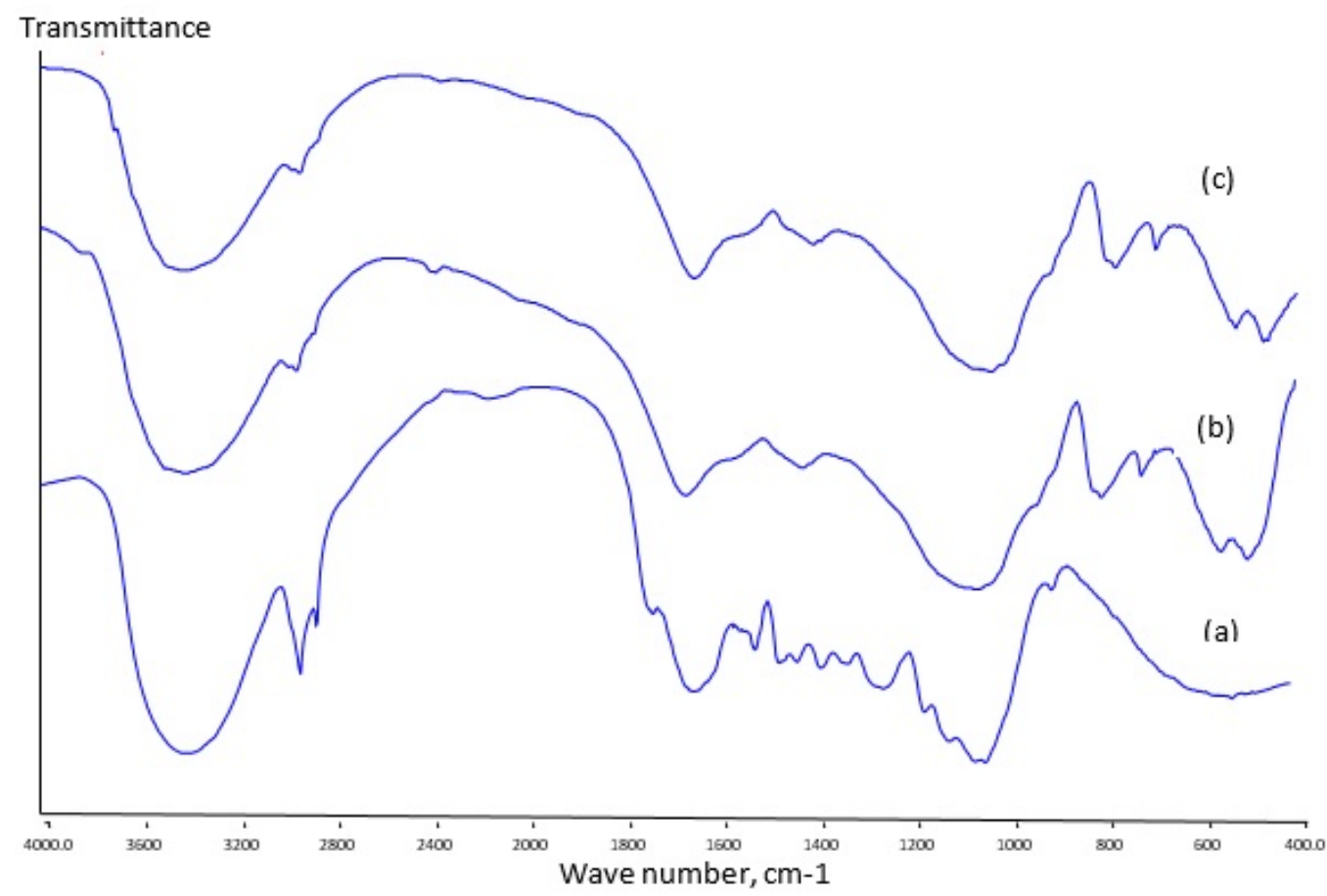

Figure 1. FTIR spectra of EFB compost A (EFB: wood chips 1:2); (a) early stage (0 month), (b) intermediate stage (1 month), and (c) final stage (2 months) of composting. 


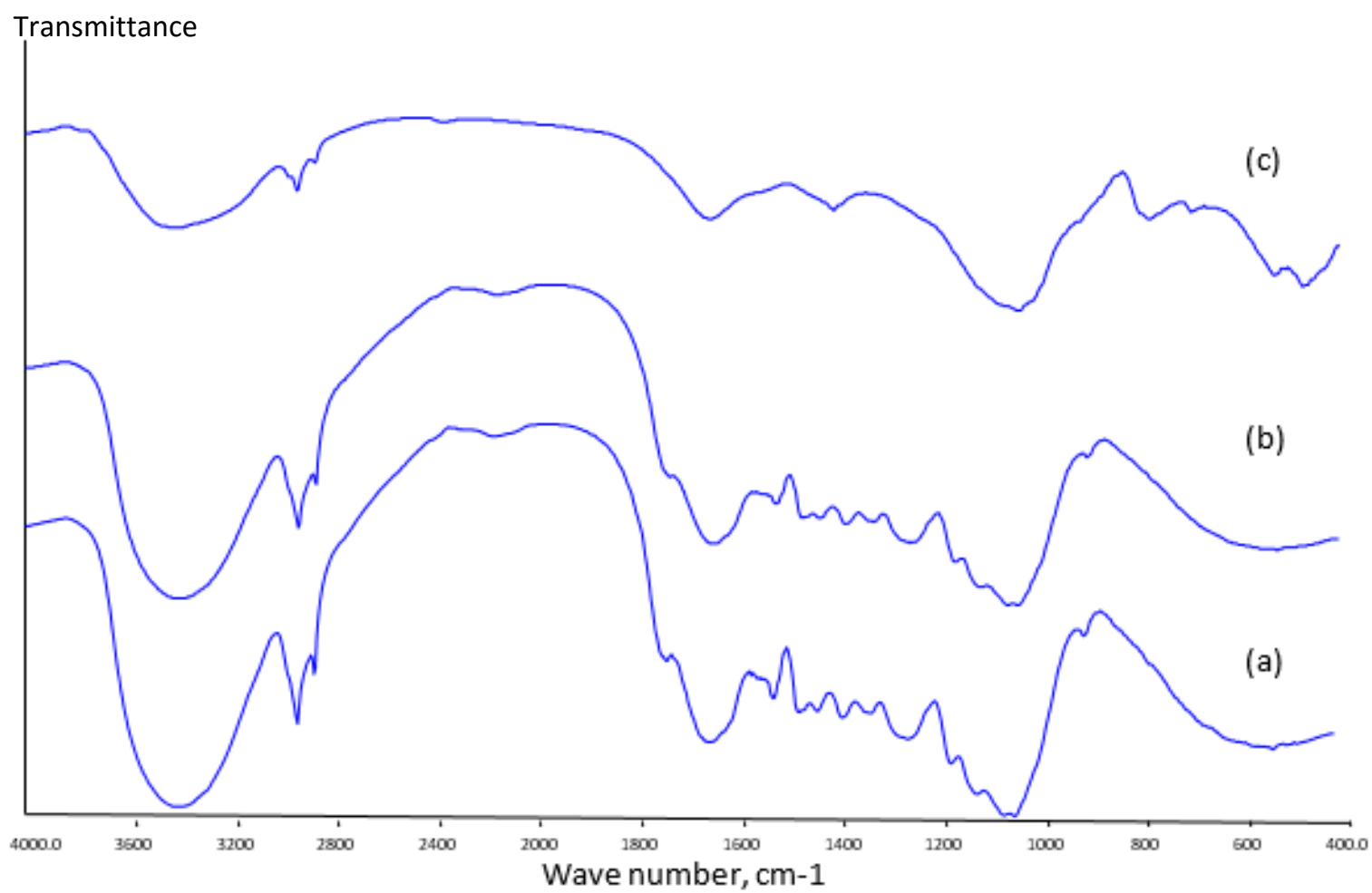

Figure 2. FTIR spectra of EFB compost B (EFB: wood chips 1:3); (a) early stage (0 month), (b) intermediate stage (1 month), and (c) final stage ( 2 months) of composting.

\section{Effect of EFB Compost on Growth R. sativs} L.

The measure of phytotoxicity effect caused by the presence of ammonia, salts, heavy metals and organic acid in the compost extract is important (Komilis \& Tziouvaras, 2009) to ensure that the compost can be effectively used. Table 4 shows that the final stage EFB composts gives higher germination index compared to the early stage compost, where the GI value were 108.30 and 102.11 for final stage compost $\mathrm{A}$ and $\mathrm{B}$, respectively. Prolonged composting duration has decreased the phytotoxicity effect of the compost. However, germination index for EFB compost B was higher in the intermediate stage compost compared to the final stage compost. Higher germination index for EFB compost $\mathrm{B}$ is envisaged to be resulted from the microorganisms' activities in the freshly added chicken manure.

The efficiency of $R$. sativs L. shoot growth in pot experiments are summarised in Figure 3. After 15 days, the shoot length of seedlings grown in early stage EFB compost A extract was 1.3 times higher compared to EFB compost $\mathrm{B}$ of the same stage. The intermediate stage of EFB compost $\mathrm{B}$ gives better shoot length compared to EFB compost A at the same stage, from day 9 to 13 of $R$. sativs $L$. growth. The final stage compost was also applied to the soil and the planted seedlings exhibited similar characteristics as in potted plants. Both composts A and B gave the same shoot length for $R$. sativs L.

Table 4. Germination index of $R$. sativs L. in EBF-compost from different stage ( 0 month: early stage, 1 month: intermediate stage; and 2 months: final stage).

\begin{tabular}{lccc}
\hline Ratio/Month & Month 0 & Month 1 & Month 2 \\
\hline $1: 2($ Compost A) & 12.00 & 108.30 & 108.30 \\
$1: 3($ Compost B) & 34.28 & 113.88 & 102.11 \\
\hline
\end{tabular}



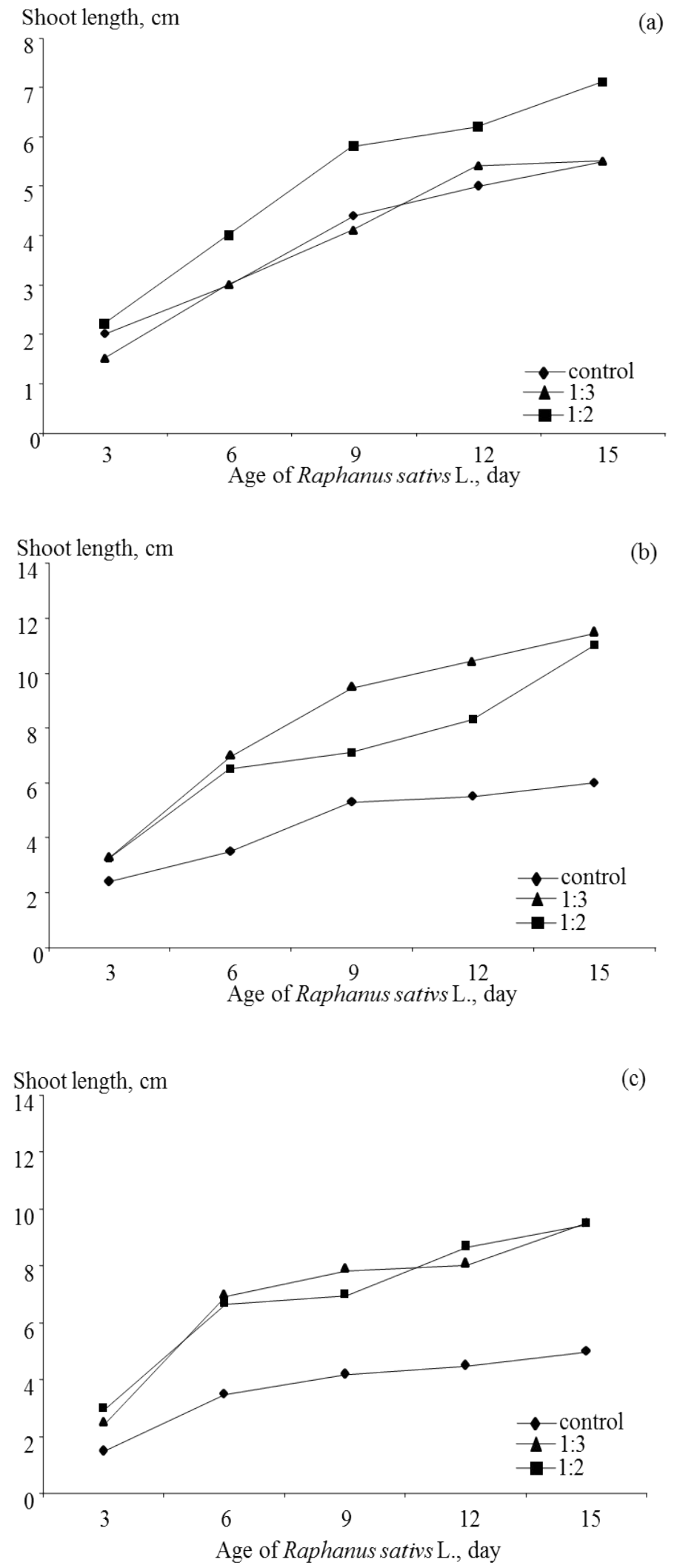

Figure 3. Shoot length of $R$. sativs L. planted with (a) early stage (0 month), (b) intermediate stage (1 month), and (c) final stage (2 months) EBF-compost. 
Figure 4 shows the difference of $R$. sativs L. leaf length during pot experiments. The $R$. sativs L. leaf length in EFB compost B was increased by $91 \%$ from its original length, while in EFB compost A the leaf-length increase was by $83 \%$. The results indicate that an increase in wood chips mass up to 3 times EFB mass resulted in better quality of EFB compost.
The results also showed that compost treated at longer time gave relatively better growth of $R$. sativs L. leaf. The results is attributed to the increase in macronutrient $(\mathrm{N}, \mathrm{C}, \mathrm{P}$ and $\mathrm{Ca})$ and micronutrient $(\mathrm{Mg}, \mathrm{Mn}, \mathrm{Fe}, \mathrm{Cu}, \mathrm{Zn}$ and $\mathrm{B})$ content in the compost as the composting process prolonged.

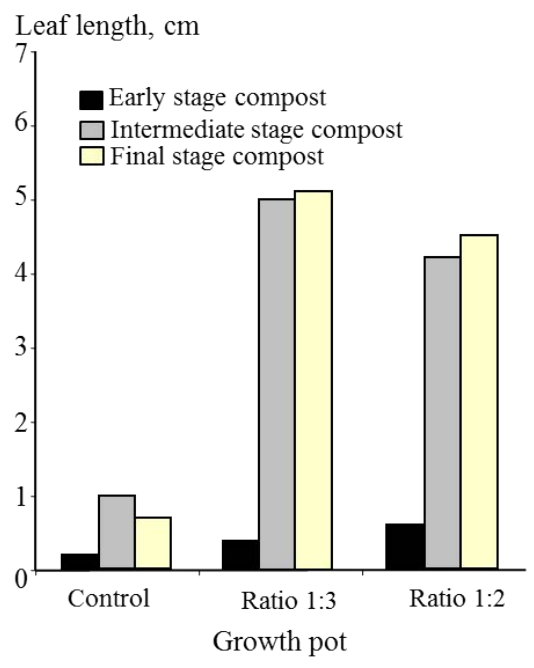

Figure 4. Leaf length of R. sativs L. grown in two EFB compost at three different phases after day 15 of growth.

\section{CONCLUSION}

EFB can be utilised as compost with the addition of wood chips as a bulking agent and chicken manure to accelerate the aerobic composting process. The composts have good mineralisation index, germination index and growth of roots and leaves of $R$. sativs L.

\section{ACKNOWLEDGEMENTS}

The authors thank Universiti Malaysia Sarawak and Ministry of Higher Education (MOHE) for financial support through FRGS/02(04)/652/2007(17).

\section{REFERENCES}

Abdul, P.M., Jahim, J.M., Harun, S., Markom, M., Lutpi, N.A., Hassan, O., Balan, V., Dale, B.E. \& Nor, M.T.M. (2016). Effects of changes in chemical and structural characteristic of ammonia fibre expansion (AFEX) pretreated oil palm empty fruit bunch fibre on enzymatic saccharification and fermentability for biohydrogen. Bioresource Technology, 211: 200-208.
Adam, S., Ahmad, S.S.N.S., Hamzah, NM. \& Darus, N.A. (2016). Composting of empty fruit bunch treated with palm oil mill effluent and decanter cake. In Regional Conference on Science, Technology and Social Sciences (RCSTSS 2014) (Pp 437-445). Springer Singapore.

Ahn, H.K., Richard, T.L. \& Choi, H.L. (2007). Mass and thermal balance during composting of a poultry manure-wood shavings mixtures at different aeration rates. Process Biochemistry, 42: 215-223.

ASTM Standard D5142. (2009) "Standard Test Methods for Proximate Analysis of the Analysis Sample of Coal and Coke", ASTM International, West Conshohocken, PA, 2003, www.astm.org.

Baharuddin, A.S., Wakisaka, M., Shirai, Y., Abd-Aziz, S. Abdul Rahman, N.A. \& Hassan, M.A. (2009). Co-composting of empty fruit bunches and partially treated palm oil mill effluents in pilot scale. International Journal of Agricultural Research, 4(2): 69-78. 
El Ouaqoudi, F.Z., El Fels, L., Lemee, L., Ambles, A. \& Hafidi, M. (2015). Evaluation of lignocelullose compost stability and maturity using spectroscopic (FTIR) and thermal (TGA/TDA) analysis. Ecological Engineering, 75: 217-222.

Horneck, D., Wysocki, D., Hopkins, B., Hart, J. \& Stevens, R. (2007). Acidifying soil for crop production: Inland Pacific Northwest. University Extension Publication EM 8917E.

Ismail, M.R., Sze, L.Y., Poulus, P. \& Ibrahim, H. (2004). The use of empty oil palm fruit bunch (EFB) compost as additive in coconut dust soilless system for vegetable crop production. Acta Horticulturae (ISHS), 644: 193-198.

Kala, D.R. Rosenani, A.B., Fauziah, C.I. \& Thohirah, L.A. (2009). Composting oil palm wastes and sewage sludge for use in potting media of ornamental plants. Malaysian Journal of Soil Science, 13: 77-9.

Komilis, D.P. \& Tziouvaras, I.S. (2009). A statistical analysis to assess the maturity and stability of six composts. Waste Management, 29: 1504-1513.
Lim, P.N., Wu, T.Y., Clarke, C. \& Nik Daud, N.N. (2015). A potential bioconversion of empty fruit bunches into organic fertilizer using Eudrilus eugeniae. International Journal of Environmental Science and Technology, 12: 2533-2544.

Outmane, A, Dorazio, V., Hafidi, M., Revel, J.C. \& Senesi, N. (2000). Elemental and spectroscopic characterization of humic acids fractionated by gel permeatation chromatography. Agronomie, 20: 491-504.

Richard, T.L., Hamelers, H.V.M., Veeken, A.H.M., \& Silva, T. (2002). Moisture relationships in composting processes. Compost Science and Utilization, 10: 286302.

Sugiharto, Y.E.C., Harimawan, A., Kresnowati, M.T.A.P., Purwadi, R., Mariyana, R., Andry, H.N.F. \& Hosen, H.F. (2016). Enzyme feeding strategies for better fed-batch enzymatic hydrolysis of empty fruit bunch, Bioresource Technology, 207: 175-179.

Vargas-García, M.D.C., Sua' rez-Estrella, F. F., López, M.J. \& Moreno, L. (2006). Influence of microbial inoculation and co-composting material on the evolution of humic-like substances during composting of horticultural wastes. Process Biochemistry, 41: 1438-1443. 